Article

\title{
Classification of Raw Stingless Bee Honeys by Bee Species Origins Using the NMR- and LC-MS-Based Metabolomics Approach
}

Muhammad Taufiq Atsifa Razali ${ }^{1}$, Zaim Akmal Zainal ${ }^{1}$, M. Maulidiani ${ }^{1}$, Khozirah Shaari ${ }^{1}$, Zulkifli Zamri ${ }^{2}$, Mohd Zainuri Mohd Idrus ${ }^{2}$, Alfi Khatib ${ }^{3}$, Faridah Abas ${ }^{1}$ (D), Yee Soon Ling 4 (iD, Lim Leong Rui ${ }^{4}$ and Intan Safinar Ismail ${ }^{1, * \text { (D) }}$

1 Laboratory of Natural Products, Institute of Bioscience, Universiti Putra Malaysia, 43400 Serdang, Selangor, Malaysia; atsifa79@gmail.com (M.T.A.R.); miaz1501@gmail.com (Z.A.Z.); maulidiani@upm.edu.my (M.M.); khozirah@yahoo.com.my (K.S.); faridah_abas@upm.edu.my (F.A.)

2 Syamille Agrofarm \& Resort Sdn. Bhd., Lot 3749 \& 3750, Jalan Lata Perahu, Kampung Chuar Hulu, Mukim Chegar Galah, 33020 Kati, Kuala Kangsar, Perak, Malaysia; zulkiflizamri@yahoo.com (Z.Z.); ctAteh18@yahoo.com (M.Z.M.I.)

3 Department of Pharmaceutical Chemistry, Kulliyyah of Pharmacy, International Islamic University Malaysia (IIUM), Jalan Sultan Ahmad Shah, Bandar Indera Mahkota, 25200 Kuantan, Pahang, Malaysia; alfikhatib@iium.edu.my

4 Biotechnology Research Institute, Universiti Malaysia Sabah, Jalan UMS, 88400 Kota Kinabalu, Sabah, Malaysia; lingyeesoon@ums.edu.my (Y.S.L.); Irlim92@gmail.com (L.L.R.)

* Correspondence: safinar@upm.edu.my; Tel.: +60-3-8947-1490; Fax: +60-3-8942-3552

Received: 16 July 2018; Accepted: 31 July 2018; Published: 28 August 2018

\begin{abstract}
The official standard for quality control of honey is currently based on physicochemical properties. However, this method is time-consuming, cost intensive, and does not lead to information on the originality of honey. This study aims to classify raw stingless bee honeys by bee species origins as a potential classifier using the NMR-LCMS-based metabolomics approach. Raw stingless bee honeys were analysed and classified by bee species origins using proton nuclear magnetic resonance $\left({ }^{1} \mathrm{H}\right.$-NMR) spectroscopy and an ultra-high performance liquid chromatography-quadrupole time of flight mass spectrometry (UHPLC-QTOF MS) in combination with chemometrics tools. The honey samples were able to be classified into three different groups based on the bee species origins of Heterotrigona itama, Geniotrigona thoracica, and Tetrigona apicalis. D-Fructofuranose (H. itama honey), $\beta$-D-Glucose, D-Xylose, $\alpha$-D-Glucose (G. thoracica honey), and L-Lactic acid, Acetic acid, L-Alanine (T. apicalis honey) ident D-Fructofuranose identified via ${ }^{1} \mathrm{H}-\mathrm{NMR}$ data and the diagnostic ions of UHPLC-QTOF MS were characterized as the discriminant metabolites or putative chemical markers. It could be suggested that the quality of honey in terms of originality and purity can be rapidly determined using the classification technique by bee species origins via the ${ }^{1} \mathrm{H}-\mathrm{NMR}$ - and UHPLC-QTOF MS-based metabolomics approach.
\end{abstract}

Keywords: classification; stingless bee honey; bee species origins; metabolomics; NMR; LC-MS; chemometrics

\section{Introduction}

Meliponiculture (beekeeping with stingless bees) is a well-known tradition in tropical countries. Nowadays, meliponiculture is much more practiced than beekeeping with honey bees of the genus Apis (apiculture) for honey production. As stipulated in the Codex Alimentarius Commission [1], honey is defined as: 
The natural sweet substance produced by honey bees from the nectar of plants or from secretions of living parts of plants or excretions of plant sucking insects on the living parts of plants, which the bees collect, transform by combining with specific substances of their own, deposit, dehydrate, store, and leave in the honey comb to ripen and mature. Blossom Honey or Nectar Honey is the honey which comes from nectars of plants. Honeydew Honey is the honey which comes mainly from excretions of plant sucking insects (Hemiptera) on the living parts of plants or secretions of living parts of plants.

This definition is specific to honey produced by honey bees, which could be any member of the genus Apis. However, the suggestion to expand the official definition of honey towards inclusion of the stingless bee has been systematically rejected for the last 10 years [2]. Therefore, the term divine elixir has been suggested for stingless bee honey as a possible alternative [3]. Although there is no recent revision made on the current definition of honey by Codex Alimentarius Commission, the term of stingless bee honey has still often been used instead of divine elixir.

The quality of honey is based on purity and originality. Purity of honey is determined by its physicochemical properties, whereas originality depends on several factors such as botanical, geographical, and entomological origins. At present, the production of stingless bee honey does not meet the great demand from consumers, thus leading to high prices and an increasing number of fraudulent practices in the market. Similar to Apis honeys, many problems have been encountered in terms of determining the purity and originality of stingless honey $[4,5]$.

Adulteration and artificial honey are examples of problems related to purity of honey. An adulterated honey was produced when a small portion of pure honey is mixed with larger portion of high-fructose corn syrup, synthetic honey-flavouring agent or even with other types of pure honey. An example of this is the practice of diluting the high commercial value of unifloral honey (e.g., some New Zealand honeys (L. scoparium (manuka), Kunzea ericoides (kanuka), and Trifolium spp. (clover)) with those of lower commercial value honey (e.g., polyfloral honey) [4]. The artificial honey is absolutely made from sugar or corn syrups together with other additive ingredients. Whereas, mislabelling of floral or geographical origin and honey laundering are some examples related to originality of honey. Honey laundering involves the process where honey was filtered to remove pollen or soil that could be used to trace it back to its origin [5].

Several scientific methods have been used to determine the quality of honey. Sugar profiling based on chromatography [6,7], sensory analysis [8], and physicochemical analyses [2,9-15] are among the techniques used to determine the purity of honey.

The existing official standard for quality control of honey is based on the physicochemical characteristics of Apis honey such as acidity, ash, diastase activity, hydroxymethylfurfural (HMF), reducing sugars, sucrose, and water content. Nevertheless, the characteristics of stingless bee honey markedly differed from Apis honey in terms of viscosity, colour, and taste [16,17]. Therefore, Vit et al. [3] have proposed the quality standard for stingless bee honeys based on the accepted standard for Apis mellifera, which could be used to detect honey impurity in stingless bee honey.

However, these physicochemical analyses do not lead to any information about the botanical and geographical origin of honey [18]. Although artificial or adulterated honeys could be manipulated to conform to the quality standard of physicochemical parameters, the consistency of their metabolite composition could not be reproduced. Moreover, these physicochemical parameters are less appropriate to be used for monitoring the quality of stingless bee honey because of their low reproducibility, wherein often give a high variability in batch-to-batch results, tedious, time-consuming, and cost intensive.

This study is important because inquiry on whether bee species origin can be used as reliable classifier remains questionable. Nowadays, the perspective of a broader and lucrative market for natural and organic products indicates a need for more rapid and reliable method in quality control of honey. An untargeted metabolomics approach might be an improvement to the existing physicochemical approach in the detection of honey originality. 
The untargeted metabolomics approach mainly consists of two interrelated steps; metabolite fingerprinting and metabolite profiling. Metabolite fingerprinting can be defined as high-throughput qualitative screening of metabolic composition of an organism or tissue with the primary aim of sample comparison and discrimination analysis. All steps from sample preparation, separation, and detection should be rapid and as simple as is feasible. Mostly, no attempt is initially made to identify the metabolites present. Metabolite fingerprinting is often used as a forerunner to metabolite profiling [19].

The next step is metabolite profiling of which can be defined as identification and quantification of the metabolites present in an organism. However, metabolite profiling is only feasible for a limited number of components, which are usually chosen on the basis of discriminant analysis or on molecular relationships based upon molecular pathways/networks [19].

It is possible to verify the botanical origin and exclude adulteration with sugars for honey [20]. Several metabolomics studies such as classification of honeys by different botanical origins $[4,21-27]$ and geographical origins $[23,28,29]$ have been carried out to address honey originality issues. To the extent of our knowledge, the untargeted metabolomics approach has not yet been applied in the classification of raw stingless bee honeys by different bee species origins within a specific geographical region.

There were also several reports from previous studies that used various types of predictors to determine the entomological origins of stingless bee honeys. For example, hexoses-to-maltose ratio in high performance liquid chromatography (HPLC) analysis was proposed as predictor (taxonomic marker) to predict entomological origins of stingless bee honeys [30]. In addition, Ramón-Sierra et al. [31] demonstrated the utility of protein profiles obtained from electrophoresis as predictor of entomological origins for stingless bee honeys. On the other hand, Kek et al. [32] showed that the entomological origins of stingless bee honeys (four different bee species) can be used as classifier to classify raw honeys using their chemical profiles and mineral contents. According to Ramón-Sierra et al. [31], it is possible to differentiate honey samples in terms of bee species origins using metabolomics tools. Therefore, this study aims to classify raw stingless bee honeys by bee species origins as a potential classifier using the NMR- and LC-MS-based metabolomics approach.

\section{Materials and Methods}

\subsection{Species Identification}

Voucher specimens of three stingless bee species identified were deposited at the Centre for Insect Systematics (CIS), Faculty of Science and Technology, Universiti Kebangsaan Malaysia, Bangi, Selangor with the following accession numbers: Heterotrigona itama (CIS-TRI-2014-002), Geniotrigona thoracica (CIS-TRI-2014-0001), and Tetrigona apicalis (CIS-TRI-2014-0004).

\subsection{Collection of Honey Samples}

Honey samples from the three stingless bee species were collected from the meliponiculture site of the Syamille Agrofarm and Resort (4.8992 ${ }^{\circ}$ N, $100.8964^{\circ}$ E), Perak, Malaysia (Figure S1). The stingless bee hives were distributed in random spots within a land area of $48,562.3 \mathrm{~m}^{2}$ and were surrounded by several species of fruit trees (Myrtaceae, Meliaceae, Oxalidaceae, Moraceae, Rutaceae, Arecaceae), ornamental trees (Polygonaceae, Asteraceae, Rubiaceae), and resin-secreting trees (Dipterocarpaceae). These hives were made from naturally hollowed tree trunks, topped with wooden nest boxes, inside were cerumen pots of resins and wax mixtures to store nectar collected by the stingless bee [33]. For each species of stingless bee, honey samples were collected from 30 cerumen pots from six different nest boxes. Hence, five cerumen pots from each nest box. The collection was made between 7:00 a.m. and 11:30 a.m. All samples were kept in a cooler box with ice for transportation to the laboratory, prior to storing in the chiller at $4{ }^{\circ} \mathrm{C}$ until further analysis. 


\section{3. ${ }^{1} H-N M R$ Spectroscopy}

\subsubsection{Chemicals and Reagents}

Potassium dihydrogen phosphate $\left(\mathrm{KH}_{2} \mathrm{PO}_{4}\right)$ and sodium deuteroxide solution $(\mathrm{NaOD}, 30 \%$ by weight in $\mathrm{D}_{2} \mathrm{O}$ ) were purchased from Merck Sharp \& Dohme (Kenilworth, NJ, USA). Methanol-d4 $\left(\mathrm{CD}_{3} \mathrm{OD}, 99.8 \%\right)$, deuterium oxide $\left(\mathrm{D}_{2} \mathrm{O}, 99.9 \%\right)$, and sodium-3-trimethylsilylpropionate (TMSP-2,2,3,3-d4, 98\%) were purchased from Cambridge Isotope Laboratories, Inc. (Tewksbury, MA, USA).

\subsubsection{Sample Preparation}

The chilled honey samples were allowed to sit at room temperature for at least $30 \mathrm{~min}$ prior preparation for data acquisition by ${ }^{1} \mathrm{H}-\mathrm{NMR}$ spectroscopy [34]. The phosphate buffer was prepared by dissolving $1.232 \mathrm{~g}$ of $\mathrm{KH}_{2} \mathrm{PO}_{4}$ and $10 \mathrm{mg}$ of TMSP $(0.01 \%)$ in $100 \mathrm{~mL}$ of $\mathrm{D}_{2} \mathrm{O}$. The buffer solution was then adjusted to $\mathrm{pH} 6$ with $1 \mathrm{M} \mathrm{NaOD}$ solution.

Honey samples for ${ }^{1} \mathrm{H}-\mathrm{NMR}$ measurement were prepared according to the procedure described by Kim et al. [34] with slight modifications. Honey in $5 \mathrm{mg}$ was dissolved in $120 \mu \mathrm{L}$ of deuterated methanol, followed by $480 \mu \mathrm{L}$ of phosphate buffer. After centrifugation at 10,000 revolutions per min (RPM) for $2 \mathrm{~min}, 600 \mu \mathrm{L}$ of the supernatant was pipetted into a round bottom NMR tube $(4.97 \mathrm{~mm} \times 4.2 \mathrm{~mm}$, $178 \mathrm{~mm}$ ) by Norell (Morganton, VA, USA) for data acquisition.

\subsubsection{Data Acquisition}

The ${ }^{1} \mathrm{H}$-NMR spectra of stingless bee honey samples were acquired in duplicates, at $25{ }^{\circ} \mathrm{C}$, on a $500 \mathrm{MHz}$ Unity Inova NMR spectrometer (Varian Inc., California, CA, USA). Each spectrum was acquired over a spectral width of 0-10 ppm, using 64 scans and acquisition time of $256.8 \mathrm{~s}$. The presaturation pulse sequence was used to suppress residual water signal with low power selective irradiation. $\mathrm{D}_{2} \mathrm{O}$ was used as internal lock and TMSP-2,2,3,3-d4 was used as reference standard at $0.00 \mathrm{ppm}$.

\subsubsection{Data Pre-processing}

${ }^{1} \mathrm{H}-\mathrm{NMR}$ spectra were automatically phased using VnmrJ version $2.3 \mathrm{~A}$ (Varian Inc., Palo Alto, CA, USA) and further pre-processed with automatic baseline correction (spline) using Chenomx NMR Suite version 6.1 (Chenomx Inc., Edmonton, AB, Canada). The spectral intensities were scaled to TMSP (set to $0.0 \mathrm{ppm}$ ) and residual methanol (3.24-3.33 ppm) and water (4.68-4.88 ppm) signals were excluded. The remaining spectral regions were divided into $0.04 \mathrm{ppm}$ bins, giving a total of 238 integrated regions (X-variables) per spectrum. The data were then converted to ASCII format and imported to Microsoft Excel 2010. A total of 79 spectra of ${ }^{1} \mathrm{H}-\mathrm{NMR}$ were acquired, binned, and used to develop the classification model.

\subsubsection{Data Analysis}

The resulting Microsoft Excel file were imported into SIMCA version 14.1 (MKS Data Analytics Solutions, Umeå, Sweden) and pareto-scaled for multivariate data analysis (MVDA). Prior to classification of the honey samples by OPLS-DA model, principal component analysis (PCA) was performed to obtain an overview of the basic variation among the honey samples and to determine the presence of outliers. The robustness of OPLS-DA model was validated by means of cross-validation and response permutation test using 100 random permutations.

\subsubsection{Characterization of Discriminant Metabolites}

Variables in the OPLS-DA model with both values of variable importance in projection of greater than one (VIP > 1) and error bar not exceeding zero were considered as discriminant metabolites. 
Characterization of discriminant metabolites was carried out based on the match between experimental ${ }^{1} \mathrm{H}-\mathrm{NMR}$ signals and reference compound of in-house library of Chenomx Profiler version 8.2 (Chenomx Inc., Edmonton, AB, Canada).

The identity of characterized metabolites was further supported by comparison of two-dimensional (2D) ${ }^{1} \mathrm{H}-{ }^{1} \mathrm{H} J$-resolved and heteronuclear single quantum correlation (HSQC) experiments with online databases such as the Human Metabolome Database (HMDB), Kyoto Encyclopedia of Genes and Genomes (KEGG), PubChem, and ChemSpider.

\subsection{UHPLC-QTOF Mass Spectrometry}

\subsubsection{Chemicals and Reagents}

LC-MS grade methanol $(\mathrm{MeOH})$ and acetonitrile $(\mathrm{ACN})$ were purchased from J.T. Baker (Philipshurg, MJ, USA). LC-MS grade ammonium acetate $\left(\mathrm{NH}_{4} \mathrm{OAc}\right)$ and formic acid $(\mathrm{HCOOH})$ and sodium formate were purchased from Sigma-Aldrich (St. Louis, MO, USA). Sodium chloride $(\mathrm{NaCl})$ was from Merck (Darmstadt, Germany). Water used in LC was purified using Milli-Q system (Millipore, Milford, MA, USA) at resistivity of $>18.2 \mathrm{M} \Omega \cdot \mathrm{cm}$.

\subsubsection{Sample Preparation}

Stingless bee honey samples (in three biological replicates per species) were randomly selected from the collected 30 replicates (Section 2.2). An aliquot of $100 \mu \mathrm{L}$ of each honey sample was mixed with $500 \mu \mathrm{L}$ of $\mathrm{MeOH}: \mathrm{ACN}$ :Water $(1: 1: 1 v / v)$ and vortexed until fully mixed. The mixture was centrifuged at 9520 relative centrifugal force (RCF) at $4{ }^{\circ} \mathrm{C}$ for $30 \mathrm{~min}$. The supernatant was then filtered and transferred into sample vial and stored at $-80{ }^{\circ} \mathrm{C}$ until further analysis. For quality control (QC) purpose, all the extracted samples $(n=9)$ were mixed.

\subsubsection{Data Acquisition}

The extracted samples were subjected to Vanquish ${ }^{\mathrm{TM}}$ Horizon UHPLC system (Thermo Fisher Scientific, Waltham, MA, USA) coupled with electrospray ionisation Impact II QTOF-mass spectrometry system (Bruker Daltonics, Bremen, Germany). Honey sample of $10 \mu \mathrm{L}$ was injected into Kinetex F5 LC column $(2.1 \mathrm{~mm} \times 100 \mathrm{~mm}, 2.6 \mu \mathrm{m}$; Phenomenex, Torrance, CA, USA). The column was maintained at $40{ }^{\circ} \mathrm{C}$ and eluted at a flow rate of $600 \mu \mathrm{L} / \mathrm{min}$ during analysis. The mobile phase was composed of solvent $\mathrm{A}$ (mixture of $\mathrm{H}_{2} \mathrm{O}, 0.1 \% \mathrm{HCOOH}$, and $1 \% \mathrm{NH}_{4} \mathrm{OAc}(10 \mathrm{mM}$ )) and solvent $\mathrm{B}$ (mixture of acetonitrile/methanol [6:4 v/v], $1 \%$ of $0.1 \% \mathrm{HCOOH}$ and $1 \% \mathrm{NH}_{4} \mathrm{OAc}(10 \mathrm{mM})$ ). The gradient elution program was initiated from $1 \%$ to $40 \%$ solvent B in $5 \mathrm{~min}$, followed by $100 \%$ solvent B from $5.1 \mathrm{~min}$ to $8 \mathrm{~min}$ and maintained for the next $2 \mathrm{~min}$. The column was conditioned with the initial gradient for $3 \mathrm{~min}$ before each sample injection.

The mass data acquisition was set to $m / z$ values of 50-1500 amu. Positive and negative mode of electrospray ionisation (ESI) were deployed at $4200 \mathrm{~V}$ and $-4200 \mathrm{~V}$, respectively. The ion source conditions were set as follows: gas temperature of $300^{\circ} \mathrm{C}$, drying gas flow at $12 \mathrm{~L} / \mathrm{min}$, and nebulizer flow at 5.0 bar. Mass calibration standard of sodium formate $(10 \mathrm{mM})$ was introduced post-column via a 6-port valve at $0.1-0.3 \mathrm{~min}$. The $\mathrm{m} / \mathrm{z}$ values of acquired data were calibrated against the introduced sodium formate and subsequently converted into netCDFdata format (*.cdf) using ACD/Spectrus Processor version 2017.1.3.

\subsubsection{Data Processing}

The mass netCDF files were processed using MZmine version 2 [35] to compensate for variations in the retention times and $m / z$ values between each analysis. Upon completion of the data processing, the mass spectral data were exported into a file with a comma-separated values data format ( ${ }^{*}$.csv) as a peak list table, with rows representing the honey samples and columns representing the integrated and normalized peak areas $(m / z$ values and retention times). 


\subsubsection{Data Analysis}

The generated csv file $\left({ }^{*} . \mathrm{csv}\right)$ was imported to SIMCA version 14.1 (MKS Data Analytics Solutions, Umeå, Sweden) and set with unit variance (UV) scaling. As with the NMR data, PCA overview was carried out prior to the PLS-DA model. The validity of the PLS-DA model was also verified by cross-validation and response permutation tests of 100 random permutations.

\subsubsection{Characterization of Diagnostic Ions}

ESI ionizes polar compounds more efficiently with basic sites $\left(\mathrm{ESI}^{+}\right)$or acidic sites $\left(\mathrm{ESI}^{-}\right)$[36]. The $m / z$ values of precursor ions (ESI ${ }^{+}$and ESI ${ }^{-}$) in the PLS-DA model with VIP $>1$ and with error bar not exceeding zero were considered as diagnostic ions. Characterization of diagnostic ions could be performed based on comparison with online databases such as Metlin, KEGG, PubChem, ChemSpider, and MetFrag. Fragmentation of diagnostic ions was also generated for essential uses in structural elucidation and confirmation of the metabolite identity.

\section{Results}

\subsection{An Overview by PCA}

\subsubsection{PCA of ${ }^{1} \mathrm{H}-\mathrm{NMR}$ Spectral Data}

An overview of PCA on ${ }^{1} \mathrm{H}-\mathrm{NMR}$ metabolite fingerprints was performed to identify outliers in the data using Hotelling's T2. The PCA score plot $(\mathrm{R} 2 \mathrm{X}=0.991 ; \mathrm{Q} 2=0.946)$, showed no observations outside the tolerance ellipse based on Hotelling's T2, indicating that there were no strong outliers present in the data (Figure S2). The three types of honey samples were seen to be separated into two main clusters by PC2. Although the H. itama honey samples were separated from those of T. apicalis, there was partial overlap of the G. thoracica honey samples with those of both H. itama and G. thoracica. Therefore, a discriminant-based classification model was developed to classify the honey samples.

\subsubsection{PCA of UHPLC-QTOF Mass Spectrometric Data}

The PCA score plots were constructed using positive $\left(\mathrm{ESI}^{+}\right)$(Figure S3) and negative (ESI ${ }^{-}$) precursor ions (Figure S4). Both score plots $\left(\mathrm{ESI}^{+}: \mathrm{R} 2 \mathrm{X}=0.61 ; \mathrm{Q} 2=0.253, \mathrm{ESI}^{-}: \mathrm{R} 2 \mathrm{X}=0.901 ; \mathrm{Q} 2=0.799\right.$ ) showed no strong outliers in the mass data of honey samples. The honey samples of three species of stingless bee were clustered well into three separate groups, justifying further data analysis using the PLS-DA classification model.

\subsection{Classification Models of MVDA}

\subsubsection{OPLS-DA $\left({ }^{1} \mathrm{H}-\mathrm{NMR}\right.$ Spectral Data)}

An OPLS-DA model was built using the ${ }^{1} \mathrm{H}-\mathrm{NMR}$ data of the honey samples. As shown by the OPLS-DA score plot (Figure 1), the honey samples were classified into three separate groups with 100\% correct classification (Table 1) according to their bee species origins. Honey samples from T. apicalis were discriminated from those of H. itama and G. thoracica honey by PC1, while H. itama honey samples were discriminated from those of G. thoracica by PC2.

For each component in PLS and OPLS models and their corresponding DA-extensions, summary of fit plot displays R2Y and Q2 bars. R2Y is the percent of variation of the training set-Y with OPLS-explained by the Y-predictive components. R2Y is a measure of fit, i.e., how well the model fits the data wherein a poor R2Y value is given when there is poor reproducibility (noisy data) in the training data set, or when for other reasons $\mathrm{X}$ does not explain $\mathrm{Y}$. Q2 indicates how well a model could predict a new data set. Q2 $>0.5$ indicates good predictability and Q2 $>0.9$ is excellent. The difference between R2Y and Q2 larger than 0.2-0.3 indicates the presence of a few outlying data points [37]. A poor $\mathrm{Q} 2$ value is given when the data is noisy, or when the relationship between $\mathrm{X}$ to $\mathrm{Y}$ is poor, or when the 
model is dominated by a few scattered outliers. In this study, the OPLS-DA model demonstrated an optimum goodness of fit $(\mathrm{R} 2 \mathrm{Y}=0.921)$ and satisfied the criteria for good predictability $(\mathrm{Q} 2=0.838)$, and the difference between R2Y and Q2 was 0.083 .

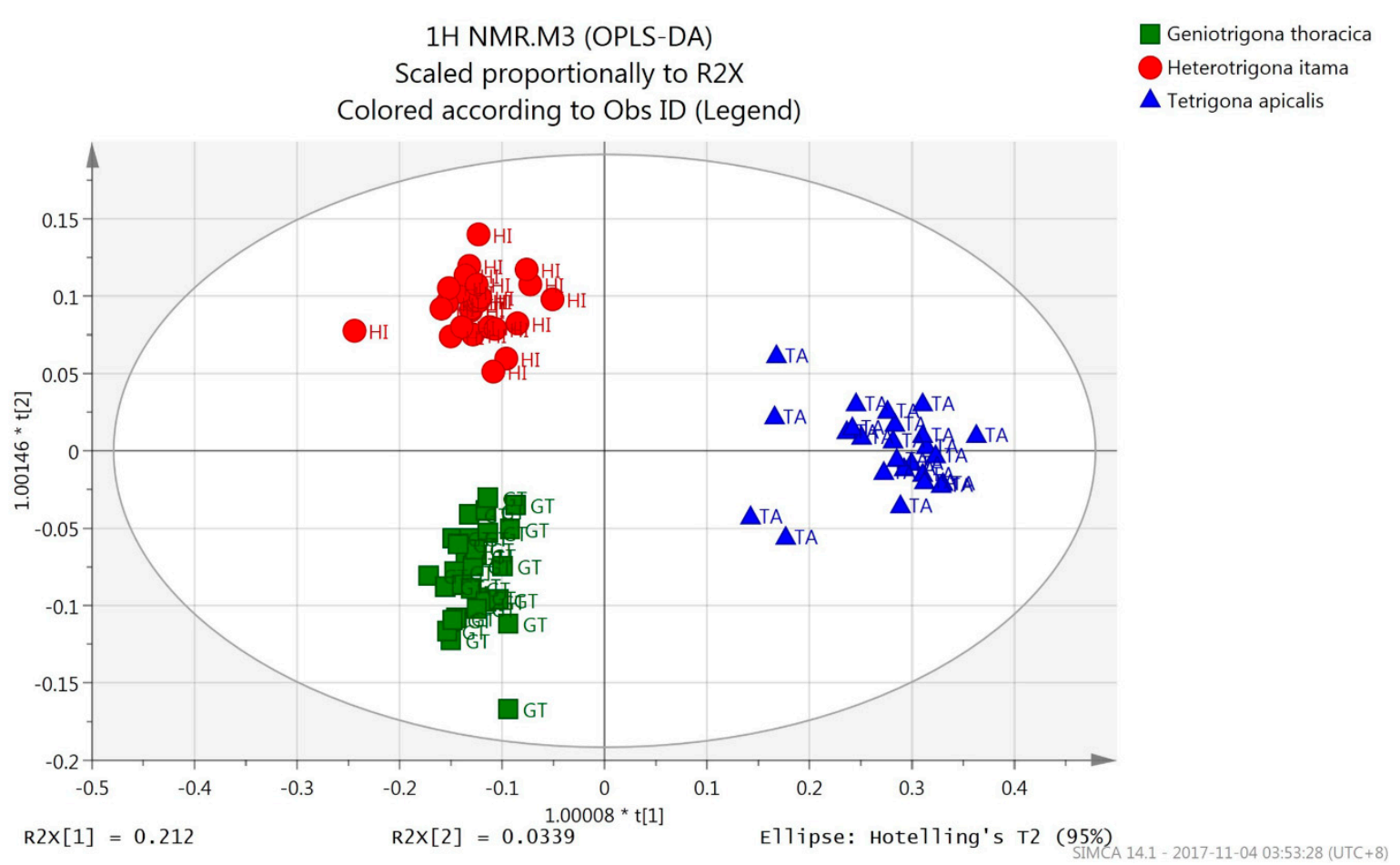

Figure 1. The OPLS-DA score scatter plot of ${ }^{1} \mathrm{H}-\mathrm{NMR}$ spectral data.

Table 1. The misclassification table for OPLS-DA model of three types of stingless bee honey.

\begin{tabular}{ccccc}
\hline \multirow{2}{*}{ Species Origin } & \multirow{2}{*}{ \% Correct } & \multicolumn{3}{c}{ Classes of Honey (OPLS-DA) } \\
\cline { 3 - 5 } & & H. itama & G. thoracica & T. apicalis \\
\hline H. itama & 100 & 25 & 0 & 0 \\
G. thoracica & 100 & 0 & 29 & 0 \\
T. apicalis & 100 & 0 & 0 & 25 \\
Total & & 25 & 29 & 25 \\
Average & 100 & & & \\
\hline
\end{tabular}

Response permutation testing aims to assess the risk whether the OPLS-DA model is spurious or not. A model could fit well to the training set, however it might not predict $Y$ well for the new observations. R2Y and Q2 of the original model are compared with R2Y and Q2 of several models based on data whereby the order of the Y-observations has been randomly permuted, while the $\mathrm{X}$-matrix was kept constant. The model is validated when R2Y-intercept does not exceed 0.3-0.4 and that the Q2-intercept does not exceed 0.05 (Eriksson et al., 2006). The present results gave $\mathrm{Y}$ intercepts of $0.382(\mathrm{R} 2),-0.58(\mathrm{Q} 2)$ for H. itama honey; $0.373(\mathrm{R} 2)$ and $-0.604(\mathrm{Q} 2)$ for G. thoracica honey and, 0.364 (R2) and -0.641 (Q2) for T. apicalis honey (Figure S5). Hence, the OPLS-DA model was verified as valid.

\subsubsection{PLS-DA (UHPLC-QTOF Mass Spectrometric Data)}

PLS-DA classification model was used instead of OPLS-DA model for UHPLC-QTOF mass spectral data. This is due to the response permutation tests of OPLS-DA models for $m / z$ values of both $\mathrm{ESI}^{+}$(Figure S6) and $\mathrm{ESI}^{-}$precursor ions (Figure S7) were shown to be overfitting. 
The PLS-DA score plots for $m / z$ values of both $\mathrm{ESI}^{+}$(Figure 2) and $\mathrm{ESI}^{-}$precursor ions (Figure 3) for the honey samples were clearly classified into three discernible groups with $100 \%$ correct classification (Table 2) according to their bee species origins. T. apicalis group was discriminated from that of $H$. itama and G. thoracica by PC1, while H. itama group was discriminated from G. thoracica by PC2. Both PLS-DA models $\left(\mathrm{ESI}^{+}: \mathrm{R} 2 \mathrm{Y}=0.922, \mathrm{Q} 2=0.833, \mathrm{R} 2 \mathrm{Y}-\mathrm{Q} 2=0.089 ; \mathrm{ESI}^{-}: \mathrm{R} 2 \mathrm{Y}=0.989\right.$, $\mathrm{Q} 2=0.976, \mathrm{R} 2 \mathrm{Y}-\mathrm{Q} 2=0.013$ ) demonstrated the optimum goodness of fit and satisfied the criteria for good predictability.

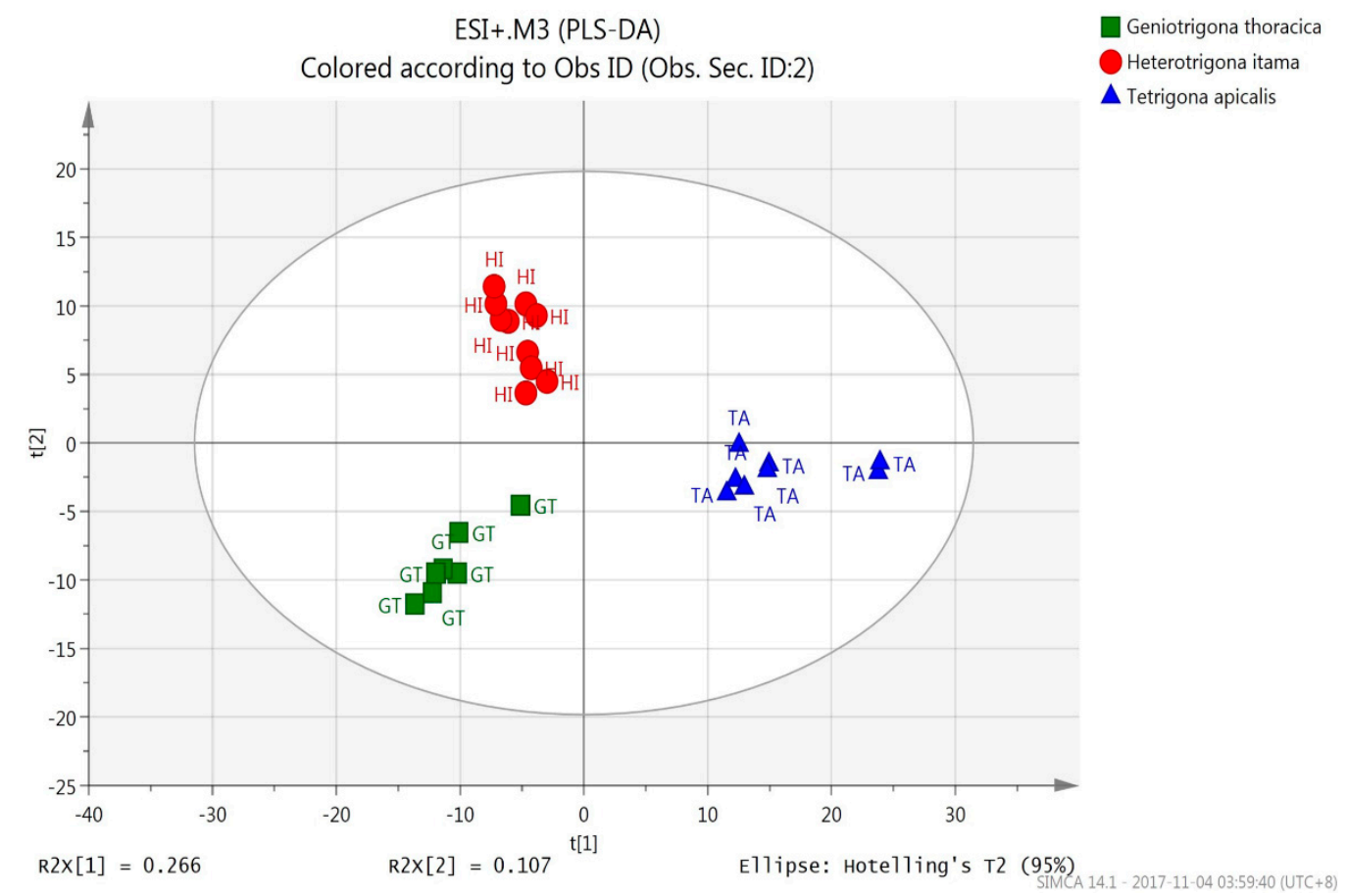

Figure 2. PLS-DA score scatter plot for $m / z$ values of ESI ${ }^{+}$precursor ions by UHPLC-QTOF MS data.

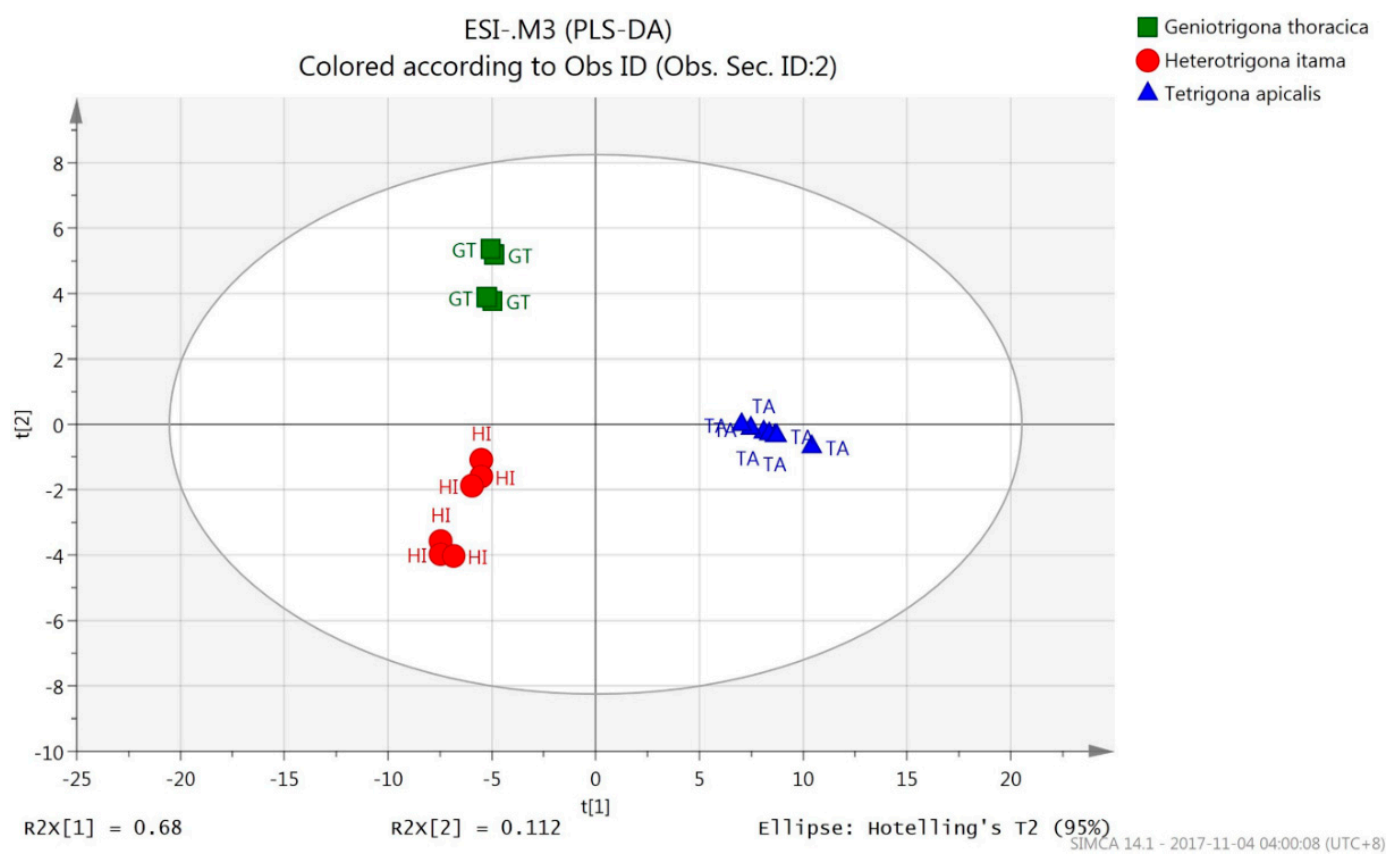

Figure 3. PLS-DA score scatter plot of for $m / z$ values of ESI ${ }^{-}$precursor ions by UHPLC-QTOF MS data. 
Table 2. The misclassification table for PLS-DA model of $m / z$ values of $\mathrm{ESI}^{+}$and $\mathrm{ESI}^{-}$precursor ions.

\begin{tabular}{cccccccc}
\hline \multirow{2}{*}{ Species Origin } & \multirow{2}{*}{ \% Correct } & \multicolumn{3}{c}{ Classes of Honey (ESI ${ }^{+}$) } & \multicolumn{3}{c}{ Classes of Honey (ESI ${ }^{-}$) } \\
\cline { 3 - 8 } & & H. itama & G. thoracica & T. apicalis & H. itama & G. thoracica & T. apicalis \\
\hline H. itama & 100 & 10 & 0 & 0 & 6 & 0 & 0 \\
G. thoracica & 100 & 0 & 7 & 0 & 0 & 4 & 0 \\
T. apicalis & 100 & 0 & 0 & 8 & 0 & 0 & 7 \\
Total & & 10 & 7 & 8 & 6 & 4 & 7 \\
\hline Average & 100 & \multicolumn{7}{c}{} \\
\hline
\end{tabular}

It is very crucial to validate the PLS-DA model via response permutation testing because there is a risk of data overfitting in this supervised classification model. Response permutation testing for the PLS-DA model of ESI ${ }^{+}$precursor ions for all honeys showed Y-intercepts of 0.391 (R2) and -0.233 (Q2) for H. itama; 0.364 (R2) and -0.234 (Q2) for G. thoracica, and 0.31 (R2), -0.3 (Q2) for T. apicalis (Figure S8). In addition, the PLS-DA model of $\mathrm{ESI}^{-}$precursor ions of $H$. itama gave Y-intercepts of $0.339(\mathrm{R} 2)$ and $-0.369(\mathrm{Q} 2)$; . thoracica of $0.316(\mathrm{R} 2)$ and $-0.365(\mathrm{Q} 2)$, and T. apicalis of $0.339(\mathrm{R} 2)$ and -0.341 (Q2) (Figure S9). Hence, all of these PLS-DA classification models for both precursor ions were verified valid.

Based on the results of OPLS-DA and PLS-DA classification models, it was obvious that the honey samples were able to be classified into three different groups by bee species origins. The metabolite contents of honey differ according to bee species origins because stingless bees might have selective affinity towards certain types of floral nectars. There are a few types of flowers that stingless bees do not frequent, typically flowers with long corolla and have very little nectar or low brix value. However, stingless bees have an affinity for inflorescences, flowers with long anters, short corollas, and clustered flower head [38]. In addition, the metabolites contents are varied due to different stingless bee species might secrete different types of enzymes to the foraged nectar. According to Kek et al. [32], the composition of honey is probably affected by the type of bee because honey-making process is highly related to enzymes added by the bees. Therefore, bee species origins could be suggested as reliable classifier in rapid determination of honey quality in terms of originality and purity using NMR-LCMS-based metabolomics approach.

\subsection{Metabolite Identification}

\subsubsection{Characterization of Discriminant Metabolites $\left({ }^{1} \mathrm{H}-\mathrm{NMR}\right.$ Spectral Data)}

The loading column plots were generated to display the interclass separation based on binned regions. Variables with VIP $>1$ (Figure S10) and with error bar not exceeding zero (Figure S11a-c) were designated as discriminant metabolites. L-Lactic acid was determined as the most influential metabolite in VIP plot of OPLS-DA model for ${ }^{1} \mathrm{H}-\mathrm{NMR}$ spectral data.

The discriminant metabolites listed in Table 3 were proposed as chemical markers for each honey type. D-Fructofuranose was the major discriminant for H. itama honey (Figure S12), while $\beta$-D-Glucose, and D-Xylose, and $\alpha$-D-Glucose were the discriminant metabolites for G. thoracica honey (Figure S12). On the other hand, the variables contributing most significantly to discrimination of T. apicalis honey from both H. itama and G. thoracica honey were L-Lactic acid, Acetic acid, and L-Alanine (Figure S12). The identities of all discriminants were further verified based on the results obtained from ${ }^{1} \mathrm{H}-{ }^{1} \mathrm{H}$ $J$-resolved experiments (Figure 4 and Figure S12). 
Table 3. List of tentative discriminant metabolites (chemical markers) based on ${ }^{1} \mathrm{H}-\mathrm{NMR}$ spectral data for each types of stingless bee honey.

\begin{tabular}{|c|c|c|c|c|c|c|c|c|}
\hline $\mathrm{VIP}>1$ & Binned Region & $\begin{array}{c}{ }^{1} \mathrm{H}-\mathrm{NMR} \\
\text { Characteristics } \\
\text { Signals }\end{array}$ & $\begin{array}{c}\text { Online HMDB } \\
\left({ }^{1} \mathrm{H}-\mathrm{NMR}\right)\end{array}$ & $J$-Resolved & $\begin{array}{l}\text { HSQC }\left({ }^{1} \mathrm{H}^{-13} \mathrm{C}\right) \\
\text { Characteristics } \\
\text { Signals }\end{array}$ & 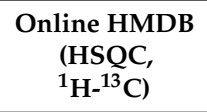 & $\begin{array}{c}\text { Tentative } \\
\text { Discriminant } \\
\text { Metabolites }\end{array}$ & Honey Types \\
\hline 4.45 & 3.68 & $3.68(\mathrm{~m})$ & \multirow{6}{*}{$4.118(\mathrm{~m})$} & \multirow{6}{*}{ d } & \multirow{6}{*}{$4.1(79.747)$} & \multirow{6}{*}{4.1055 (78.2044) } & \multirow{6}{*}{ D-Fructofuranose } & \multirow{6}{*}{ H. itama } \\
\hline 3.56 & 3.52 & $3.52(\mathrm{~m})$ & & & & & & \\
\hline 3.32 & 4.00 & $4.00(\mathrm{~m})$ & & & & & & \\
\hline 3.13 & 4.08 & $4.10(\mathrm{~d}, 8.5)$ & & & & & & \\
\hline 2.62 & 3.76 & $3.76(\mathrm{~m})$ & & & & & & \\
\hline 2.09 & 3.96 & $3.96(\mathrm{~m})$ & & & & & & \\
\hline 2.19 & 4.60 & $4.61(\mathrm{~d}, 7.9)$ & $4.634(\mathrm{~d}, 7.957)$ & d & 4.61 (94.048) & $4.6333(98.7123)$ & $\beta$-D-Glucose & \multirow{4}{*}{ G. thoracica } \\
\hline 1.77 & 3.20 & $3.21(\mathrm{dd}, 9.4,8.71)$ & $\begin{array}{l}3.21(\mathrm{dd}, 9.33) \\
3.21(\mathrm{dd}, 7.90)\end{array}$ & d & $3.2140(76.4140)$ & 3.2144 (76.9117) & D-Xylose & \\
\hline 1.44 & 5.20 & $5.20(\mathrm{~d}, 3.7)$ & $5.223(\mathrm{~d}, 3.677)$ & $\mathrm{d}$ & $5.2(93.293)$ & $5.2241(94.9364)$ & $\alpha$-D-Glucose & \\
\hline 1.25 & 2.00 & $2.05(\mathrm{~s})$ & - & - & - & - & Unassigned (2.05) & \\
\hline 3.81 & 1.32 & $1.36(\mathrm{~d}, 6.90)$ & $1.32(\mathrm{~d}, 6.96)$ & $\mathrm{d}$ & $1.387(21.841)$ & $1.3142(22.9033)$ & L-Lactic acid & \multirow{4}{*}{ T. apicalis } \\
\hline 2.88 & 1.92 & $1.92(\mathrm{~s})$ & $1.91(\mathrm{~s})$ & $\mathrm{s}$ & $1.943(26.751)$ & $1.9059(26.0899)$ & Acetic acid & \\
\hline 1.47 & 5.28 & $5.28(t, 3.6)$ & - & - & - & - & Unassigned (5.28) & \\
\hline 1.22 & 1.44 & $1.43(\mathrm{~d}, 7.00)$ & $1.46(\mathrm{~d}, 7.14)$ & d & 1.450 (19.702) & $1.4903(19.0295)$ & L-Alanine & \\
\hline
\end{tabular}




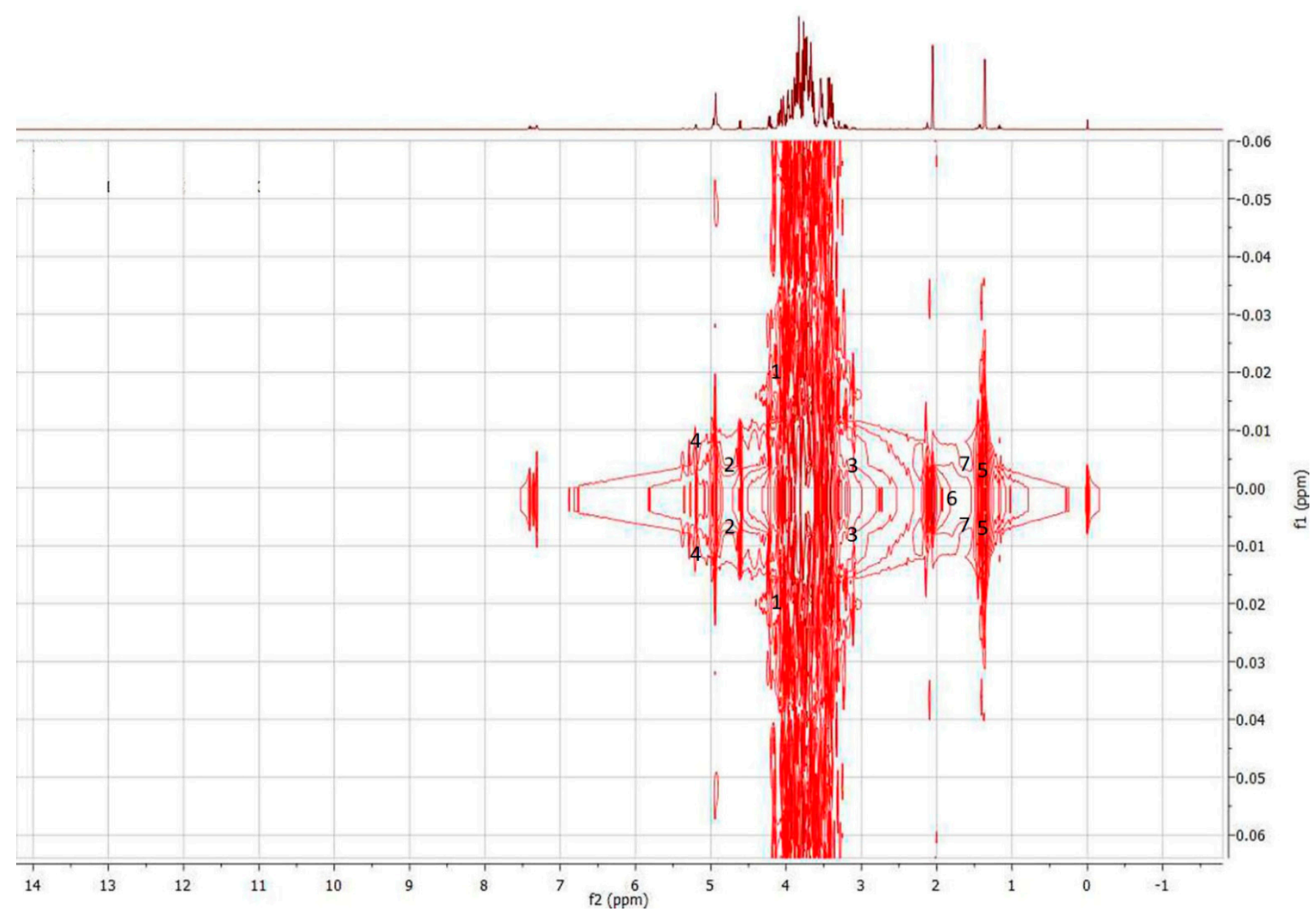

Figure 4. ${ }^{1} \mathrm{H}-{ }^{1} \mathrm{H}$ J-resolved spectrum of T. apicalis honey in the region of 0.3-10.0 ppm. 1, D-Fructofuranose; 2, $\beta$-D-Glucose; 3, D-Xylose; 4, $\alpha$-D-Glucose; 5 , L-Lactic acid; 6, Acetic acid; 7, L-Alanine. 


\subsubsection{Characterization of Diagnostic Ions (UHPLC-QTOF Mass Spectrometric Data)}

The diagnostic ions of ESI-MS fingerprints responsible for group separation among H. itama, G. thoracica, and T. apicalis honeys were as listed in Table $4 \mathrm{a}-\mathrm{c}$, respectively. There were uncharacterized metabolites that differentiated the three honey types with $m / z$ value of $446.203[\mathrm{M}+\mathrm{H}]^{+}$being the most influential diagnostic ion (VIP = 1.91) in PLS-DA model of UHPLC-QTOF mass spectrometric data (Table 4a). The major contributor to H. itama honey was $446.203 \mathrm{~m} / z[\mathrm{M}+\mathrm{H}]^{+}$(Table 4a), while $401.311 \mathrm{~m} / \mathrm{z}[\mathrm{M}-\mathrm{H}]^{-}$was the diagnostic ion for $\mathrm{G}$. thoracica honey (VIP $=1.83$ ) (Table $\left.4 \mathrm{~b}\right)$. T. apicalis honey was discriminated from $H$. itama and G. thoracica honey by $m / z$ of $277.178[\mathrm{M}+\mathrm{H}]^{+}$with VIP $=$ 1.45 (Table 4c).

Table 4. (a) List of diagnostic ions for H. itama honey based on UHPLC-QTOF mass spectrometric data. (b) List of diagnostic ions for G. thoracica honey based on UHPLC-QTOF mass spectrometric data. (c) List of diagnostic ions for T. apicalis honey based on UHPLC-QTOF mass spectrometric data.

\begin{tabular}{|c|c|c|c|c|c|}
\hline \multicolumn{6}{|c|}{ (a) } \\
\hline $\mathrm{VIP}>1$ & $\begin{array}{c}\text { Var ID } \\
\text { (Primary) }\end{array}$ & Ion & RT (min) & $\begin{array}{c}\text { Experimental } \\
\text { Precursor Ions }(\mathrm{m} / \mathrm{z})\end{array}$ & $\begin{array}{l}\text { Experimental MS-MS } \\
\text { Fragment Ions }(\mathrm{m} / \mathrm{z})\end{array}$ \\
\hline 1.66 & 492 & {$[\mathrm{M}+\mathrm{H}]^{+}$} & 1.44 & 193.087 & $\begin{array}{l}165.092,162.068,147.044, \\
135.044,133.065,105.071\end{array}$ \\
\hline 1.62 & 493 & {$[\mathrm{M}+\mathrm{H}]^{+}$} & 1.50 & 151.076 & \\
\hline 1.91 & 428 & {$[\mathrm{M}+\mathrm{H}]^{+}$} & 1.55 & 446.203 & \\
\hline 1.66 & 399 & {$[\mathrm{M}+\mathrm{H}]^{+}$} & 1.55 & 105.070 & \\
\hline 1.83 & 359 & {$[\mathrm{M}+\mathrm{H}]^{+}$} & 1.56 & 122.096 & $106.073,105.070,103.054$ \\
\hline 1.79 & 396 & {$[\mathrm{M}+\mathrm{H}]^{+}$} & 1.57 & 266.139 & \\
\hline 1.78 & 397 & {$[\mathrm{M}+\mathrm{H}]^{+}$} & 1.57 & 284.150 & $\begin{array}{c}268.145,267.143,266.139 \\
249.132,248.129,164.107 \\
134.097,105.070\end{array}$ \\
\hline 1.77 & 451 & {$[\mathrm{M}+\mathrm{H}]^{+}$} & 1.57 & 267.142 & \\
\hline 1.72 & 431 & {$[\mathrm{M}+\mathrm{H}]^{+}$} & 1.80 & 392.133 & \\
\hline 1.71 & 401 & {$[\mathrm{M}+\mathrm{H}]^{+}$} & 1.80 & 225.110 & $\begin{array}{c}181.084,165.055,139.076, \\
121.065\end{array}$ \\
\hline 1.15 & 490 & {$[\mathrm{M}+\mathrm{H}]^{+}$} & 1.80 & 234.150 & $\begin{array}{c}191.105,189.091,122.032 \\
121.029,114.128\end{array}$ \\
\hline 1.08 & 276 & {$[\mathrm{M}+\mathrm{H}]^{+}$} & 3.03 & 362.327 & \\
\hline 1.07 & 120 & {$[\mathrm{M}+\mathrm{H}]^{+}$} & 4.94 & 310.311 & \\
\hline 1.03 & 188 & {$[\mathrm{M}+\mathrm{H}]^{+}$} & 4.95 & 695.361 & \\
\hline 1.08 & 226 & {$[\mathrm{M}+\mathrm{H}]^{+}$} & 5.04 & 637.307 & \\
\hline 1.03 & 216 & {$[\mathrm{M}+\mathrm{H}]^{+}$} & 5.04 & 695.360 & $\begin{array}{l}659.294,581.245,359.032, \\
330.992,289.006,135.004\end{array}$ \\
\hline 1.47 & 416 & {$[\mathrm{M}+\mathrm{H}]^{+}$} & 5.13 & 358.309 & $\begin{array}{l}178.945,177.013,136.006, \\
135.003,132.987,123.117 \\
120.987,105.068,104.992\end{array}$ \\
\hline 1.22 & 418 & {$[\mathrm{M}+\mathrm{H}]^{+}$} & 5.13 & 336.327 & \\
\hline 1.05 & 470 & {$[\mathrm{M}+\mathrm{H}]^{+}$} & 5.27 & 371.102 & \\
\hline 1.57 & 19 & {$[\mathrm{M}+\mathrm{H}]^{+}$} & 5.54 & 360.324 & $358.365,135.004$ \\
\hline 1.56 & 124 & {$[\mathrm{M}+\mathrm{H}]^{+}$} & 5.54 & 321.316 & \\
\hline 1.55 & 8 & {$[\mathrm{M}+\mathrm{H}]^{+}$} & 5.54 & 338.343 & \\
\hline 1.52 & 107 & {$[\mathrm{M}+\mathrm{H}]^{+}$} & 5.54 & 675.678 & $\begin{array}{c}\text { 338.343, } 321.316,303.305 \\
\text { 149.133, } 135.117,111.117 \\
97.102\end{array}$ \\
\hline 1.05 & 444 & {$[\mathrm{M}+\mathrm{H}]^{+}$} & 6.07 & 679.366 & \\
\hline 1.45 & 410 & {$[\mathrm{M}+\mathrm{H}]^{+}$} & 6.09 & 366.374 & \\
\hline 1.15 & 78 & {$[\mathrm{M}-\mathrm{H}]^{-}$} & 1.00 & 668.224 & \\
\hline 1.17 & 50 & {$[\mathrm{M}-\mathrm{H}]^{-}$} & 1.69 & 495.183 & \\
\hline 1.63 & 60 & {$[\mathrm{M}-\mathrm{H}]^{-}$} & 1.73 & 493.168 & \\
\hline 1.57 & 39 & {$[\mathrm{M}-\mathrm{H}]^{-}$} & 1.82 & 119.114 & \\
\hline 1.66 & 42 & {$[\mathrm{M}-\mathrm{H}]^{-}$} & 1.83 & 353.112 & $\begin{array}{c}227.051,211.030,190.984, \\
166.013,165.009,147.014, \\
120.048,119.046\end{array}$ \\
\hline 1.27 & 31 & {$[\mathrm{M}-\mathrm{H}]^{-}$} & 1.83 & 147.098 & \\
\hline 1.16 & 29 & {$[\mathrm{M}-\mathrm{H}]^{-}$} & 1.83 & 165.102 & \\
\hline 1.41 & 46 & {$[\mathrm{M}-\mathrm{H}]^{-}$} & 1.86 & 206.118 & \\
\hline 1.15 & 45 & {$[\mathrm{M}-\mathrm{H}]^{-}$} & 2.37 & 201.075 & \\
\hline
\end{tabular}


Table 4. Cont.

\begin{tabular}{|c|c|c|c|c|c|}
\hline \multicolumn{6}{|c|}{ (b) } \\
\hline VIP > 1 & $\begin{array}{c}\text { Var ID } \\
\text { (Primary) }\end{array}$ & Ion & RT (min) & $\begin{array}{c}\text { Experimental } \\
\text { Precursor Ions }(\mathrm{m} / \mathrm{z})\end{array}$ & $\begin{array}{l}\text { Experimental MS-MS } \\
\text { Fragment Ions }(\mathrm{m} / \mathrm{z})\end{array}$ \\
\hline 1.62 & 126 & {$[\mathrm{M}+\mathrm{H}]^{+}$} & 1.03 & 365.106 & \\
\hline 1.32 & 475 & {$[\mathrm{M}+\mathrm{H}]^{+}$} & 1.13 & 174.149 & \\
\hline 1.32 & 283 & {$[\mathrm{M}+\mathrm{H}]^{+}$} & 1.30 & 365.106 & \\
\hline 1.44 & 301 & {$[\mathrm{M}+\mathrm{H}]^{+}$} & 1.41 & 203.053 & \\
\hline 1.33 & 348 & {$[\mathrm{M}+\mathrm{H}]^{+}$} & 1.69 & 365.106 & \\
\hline 1.44 & 521 & {$[\mathrm{M}+\mathrm{H}]^{+}$} & 1.81 & 351.142 & \\
\hline 1.46 & 502 & {$[\mathrm{M}+\mathrm{H}]^{+}$} & 1.82 & 317.114 & \\
\hline 1.46 & 502 & {$[\mathrm{M}+\mathrm{H}]^{+}$} & 1.82 & 317.114 & \\
\hline 1.33 & 501 & {$[\mathrm{M}+\mathrm{H}]^{+}$} & 1.97 & 227.083 & $\begin{array}{c}210.074,209.071,199.087 \\
181.076,154.065\end{array}$ \\
\hline 1.36 & 517 & {$[\mathrm{M}+\mathrm{H}]^{+}$} & 1.99 & 521.272 & $\begin{array}{l}519.256,518.236,517.228, \\
366.109,365.106,285.887, \\
218.941,203.050,185.042, \\
140.070,135.004,132.985\end{array}$ \\
\hline 1.46 & 528 & {$[\mathrm{M}+\mathrm{H}]^{+}$} & 2.01 & 301.118 & \\
\hline 1.46 & 528 & {$[\mathrm{M}+\mathrm{H}]^{+}$} & 2.01 & 301.118 & \\
\hline 1.46 & 528 & {$[\mathrm{M}+\mathrm{H}]^{+}$} & 2.01 & 301.118 & \\
\hline 1.46 & 528 & {$[\mathrm{M}+\mathrm{H}]^{+}$} & 2.01 & 301.118 & \\
\hline 1.27 & 479 & {$[\mathrm{M}+\mathrm{H}]^{+}$} & 2.05 & 321.131 & $\begin{array}{l}319.210,319.161,281.016 \\
279.020,187.060,142.948\end{array}$ \\
\hline 1.30 & 388 & {$[\mathrm{M}+\mathrm{H}]^{+}$} & 2.08 & 183.091 & $\begin{array}{c}182.154,155.047,127.016 \\
98.984\end{array}$ \\
\hline 1.35 & 516 & {$[\mathrm{M}+\mathrm{H}]^{+}$} & 2.11 & 551.283 & \\
\hline 1.41 & 483 & {$[\mathrm{M}+\mathrm{H}]^{+}$} & 4.91 & 439.375 & \\
\hline 1.43 & 421 & {$[\mathrm{M}+\mathrm{H}]^{+}$} & 5.27 & 367.319 & \\
\hline 1.51 & 503 & {$[\mathrm{M}+\mathrm{H}]^{+}$} & 5.35 & 393.334 & \\
\hline 1.80 & 478 & {$[\mathrm{M}+\mathrm{H}]^{+}$} & 5.49 & 467.408 & \\
\hline 1.25 & 520 & {$[\mathrm{M}+\mathrm{H}]^{+}$} & 5.73 & 481.387 & \\
\hline 1.00 & 486 & {$[\mathrm{M}+\mathrm{H}]^{+}$} & 5.78 & 637.469 & \\
\hline 1.46 & 519 & {$[\mathrm{M}+\mathrm{H}]^{+}$} & 5.87 & 391.320 & \\
\hline 1.68 & 87 & {$[\mathrm{M}-\mathrm{H}]^{-}$} & 4.86 & 345.255 & \\
\hline 1.80 & 86 & {$[\mathrm{M}-\mathrm{H}]^{-}$} & 5.42 & 373.283 & \\
\hline 1.83 & 88 & {$[\mathrm{M}-\mathrm{H}]^{-}$} & 5.93 & 401.311 & \\
\hline \multicolumn{6}{|c|}{ (c) } \\
\hline VIP > 1 & $\begin{array}{c}\text { Var ID } \\
\text { (Primary) }\end{array}$ & Ion & RT (min) & $\begin{array}{c}\text { Experimental } \\
\text { Precursor Ions }(\mathrm{m} / \mathrm{z})\end{array}$ & $\begin{array}{l}\text { Experimental MS-MS } \\
\text { Fragment Ions }(\mathrm{m} / \mathrm{z})\end{array}$ \\
\hline 1.07 & 364 & {$[\mathrm{M}+\mathrm{H}]^{+}$} & 1.45 & 492.207 & $\begin{array}{c}\text { 408.165, 332.243, 292.119, } \\
\text { 264.124, 244.097, 166.086, } \\
121.084,120.081\end{array}$ \\
\hline 1.13 & 183 & {$[\mathrm{M}+\mathrm{H}]^{+}$} & 1.61 & 158.082 & \\
\hline 1.12 & 245 & {$[\mathrm{M}+\mathrm{H}]^{+}$} & 1.62 & 178.086 & \\
\hline 1.22 & 110 & {$[\mathrm{M}+\mathrm{H}]^{+}$} & 1.64 & 389.178 & \\
\hline 1.23 & 171 & {$[\mathrm{M}+\mathrm{H}]^{+}$} & 1.67 & 515.173 & \\
\hline 1.26 & 250 & {$[\mathrm{M}+\mathrm{H}]^{+}$} & 1.68 & 238.108 & \\
\hline 1.11 & 208 & {$[\mathrm{M}+\mathrm{H}]^{+}$} & 1.68 & 535.236 & \\
\hline 1.27 & 362 & {$[\mathrm{M}+\mathrm{H}]^{+}$} & 1.69 & 311.113 & \\
\hline 1.27 & 111 & {$[\mathrm{M}+\mathrm{H}]^{+}$} & 1.69 & 227.126 & \\
\hline 1.30 & 140 & {$[\mathrm{M}+\mathrm{H}]^{+}$} & 1.70 & 353.121 & \\
\hline 1.19 & 146 & {$[\mathrm{M}+\mathrm{H}]^{+}$} & 1.71 & 373.183 & \\
\hline 1.21 & 119 & {$[\mathrm{M}+\mathrm{H}]^{+}$} & 1.73 & 211.131 & \\
\hline 1.14 & 137 & {$[\mathrm{M}+\mathrm{H}]^{+}$} & 1.83 & 260.090 & \\
\hline 1.04 & 191 & {$[\mathrm{M}+\mathrm{H}]^{+}$} & 1.83 & 401.171 & \\
\hline 1.02 & 373 & {$[\mathrm{M}+\mathrm{H}]^{+}$} & 1.78 & 107.085 & \\
\hline 1.00 & 365 & {$[\mathrm{M}+\mathrm{H}]^{+}$} & 1.80 & 180.102 & \\
\hline 1.07 & 369 & {$[\mathrm{M}+\mathrm{H}]^{+}$} & 1.81 & 151.112 & \\
\hline 1.19 & 85 & {$[\mathrm{M}+\mathrm{H}]^{+}$} & 1.84 & 120.081 & \\
\hline 1.15 & 142 & {$[\mathrm{M}+\mathrm{H}]^{+}$} & 1.85 & 649.269 & \\
\hline 1.30 & 141 & {$[\mathrm{M}+\mathrm{H}]^{+}$} & 1.86 & 192.103 & \\
\hline 1.02 & 195 & {$[\mathrm{M}+\mathrm{H}]^{+}$} & 1.86 & 230.080 & \\
\hline 1.17 & 215 & {$[\mathrm{M}+\mathrm{H}]^{+}$} & 1.93 & 162.091 & \\
\hline 1.09 & 381 & {$[\mathrm{M}+\mathrm{H}]^{+}$} & 1.95 & 644.313 & \\
\hline 1.17 & 382 & {$[\mathrm{M}+\mathrm{H}]^{+}$} & 1.96 & 283.152 & \\
\hline 1.17 & 382 & {$[\mathrm{M}+\mathrm{H}]^{+}$} & 1.96 & 283.152 & \\
\hline 1.15 & 246 & {$[\mathrm{M}+\mathrm{H}]^{+}$} & 1.96 & 153.127 & \\
\hline 1.15 & 246 & {$[\mathrm{M}+\mathrm{H}]^{+}$} & 1.96 & 153.127 & \\
\hline 1.28 & 17 & {$[\mathrm{M}+\mathrm{H}]^{+}$} & 2.00 & 487.215 & \\
\hline
\end{tabular}


Table 4. Cont.

\begin{tabular}{|c|c|c|c|c|c|}
\hline \multicolumn{6}{|c|}{ (c) } \\
\hline $\mathrm{VIP}>1$ & $\begin{array}{c}\text { Var ID } \\
\text { (Primary) }\end{array}$ & Ion & RT (min) & $\begin{array}{c}\text { Experimental } \\
\text { Precursor Ions }(\mathrm{m} / \mathrm{z})\end{array}$ & $\begin{array}{l}\text { Experimental MS-MS } \\
\text { Fragment Ions }(\mathrm{m} / \mathrm{z})\end{array}$ \\
\hline 1.26 & 69 & {$[\mathrm{M}+\mathrm{H}]^{+}$} & 2.00 & 482.260 & $\begin{array}{c}355.174,335.095,154.131, \\
153.128,135.117,115.039, \\
97.028\end{array}$ \\
\hline 1.08 & 249 & {$[\mathrm{M}+\mathrm{H}]^{+}$} & 2.00 & 171.138 & \\
\hline 1.13 & 112 & {$[\mathrm{M}+\mathrm{H}]^{+}$} & 2.02 & 153.127 & \\
\hline 1.04 & 42 & {$[\mathrm{M}+\mathrm{H}]^{+}$} & 2.04 & 355.173 & \\
\hline 1.01 & 368 & {$[\mathrm{M}+\mathrm{H}]^{+}$} & 2.14 & 253.142 & \\
\hline 1.39 & 175 & {$[\mathrm{M}+\mathrm{H}]^{+}$} & 2.23 & 293.173 & \\
\hline 1.14 & 394 & {$[\mathrm{M}+\mathrm{H}]^{+}$} & 2.26 & 307.152 & \\
\hline 1.00 & 372 & {$[\mathrm{M}+\mathrm{H}]^{+}$} & 2.26 & 267.158 & \\
\hline 1.34 & 392 & {$[\mathrm{M}+\mathrm{H}]^{+}$} & 2.30 & 195.138 & \\
\hline 1.34 & 392 & {$[\mathrm{M}+\mathrm{H}]^{+}$} & 2.30 & 195.138 & \\
\hline 1.37 & 383 & {$[\mathrm{M}+\mathrm{H}]^{+}$} & 2.33 & 249.146 & \\
\hline 1.32 & 391 & {$[\mathrm{M}+\mathrm{H}]^{+}$} & 2.38 & 253.179 & \\
\hline 1.27 & 237 & {$[\mathrm{M}+\mathrm{H}]^{+}$} & 2.38 & 291.157 & \\
\hline 1.38 & 200 & {$[\mathrm{M}+\mathrm{H}]^{+}$} & 2.41 & 439.230 & \\
\hline 1.30 & 377 & {$[\mathrm{M}+\mathrm{H}]^{+}$} & 2.42 & 221.154 & \\
\hline 1.44 & 393 & {$[\mathrm{M}+\mathrm{H}]^{+}$} & 2.44 & 217.159 & \\
\hline 1.34 & 189 & {$[\mathrm{M}+\mathrm{H}]^{+}$} & 2.45 & 235.170 & \\
\hline 1.37 & 193 & {$[\mathrm{M}+\mathrm{H}]^{+}$} & 2.47 & 423.235 & \\
\hline 1.06 & 253 & {$[\mathrm{M}+\mathrm{H}]^{+}$} & 2.47 & 251.165 & \\
\hline 1.36 & 201 & {$[\mathrm{M}+\mathrm{H}]^{+}$} & 2.48 & 275.162 & \\
\hline 1.02 & 260 & {$[\mathrm{M}+\mathrm{H}]^{+}$} & 2.49 & 233.154 & \\
\hline 1.00 & 232 & {$[\mathrm{M}+\mathrm{H}]^{+}$} & 2.52 & 421.219 & \\
\hline 1.45 & 65 & {$[\mathrm{M}+\mathrm{H}]^{+}$} & 2.61 & 277.178 & \\
\hline 1.11 & 154 & {$[\mathrm{M}+\mathrm{H}]^{+}$} & 2.63 & 223.169 & \\
\hline 1.42 & 95 & {$[\mathrm{M}+\mathrm{H}]^{+}$} & 2.73 & 219.175 & \\
\hline 1.06 & 248 & {$[\mathrm{M}+\mathrm{H}]^{+}$} & 2.76 & 237.185 & \\
\hline 1.09 & 255 & {$[\mathrm{M}+\mathrm{H}]^{+}$} & 2.77 & 261.183 & \\
\hline 1.40 & 92 & {$[\mathrm{M}+\mathrm{H}]^{+}$} & 2.89 & 511.340 & \\
\hline 1.11 & 330 & {$[\mathrm{M}+\mathrm{H}]^{+}$} & 3.05 & 272.259 & \\
\hline 1.17 & 412 & {$[\mathrm{M}+\mathrm{H}]^{+}$} & 3.67 & 359.030 & \\
\hline 1.26 & 93 & {$[\mathrm{M}+\mathrm{H}]^{+}$} & 3.73 & 359.030 & \\
\hline 1.09 & 75 & {$[\mathrm{M}+\mathrm{H}]^{+}$} & 4.06 & 711.131 & \\
\hline 1.00 & 367 & {$[\mathrm{M}+\mathrm{H}]^{+}$} & 4.95 & 359.030 & $\begin{array}{c}358.368,358.309,342.310, \\
341.307,285.279,267.271, \\
136.007,135.003,123.117, \\
109.102\end{array}$ \\
\hline 1.07 & 194 & {$[\mathrm{M}+\mathrm{H}]^{+}$} & 5.00 & 359.030 & \\
\hline 1.04 & 61 & {$[\mathrm{M}+\mathrm{H}]^{+}$} & 5.45 & 983.202 & \\
\hline - & - & {$[\mathrm{M}-\mathrm{H}]^{-}$} & - & - & - \\
\hline
\end{tabular}

VIP value of more than one (VIP > 1), which has an above average influence on $Y$ summarised the influence of every term in the matrix X on all the Y's [37]. The variability in the metabolite fingerprints of stingless bee honey related to the bee species origins observed via ${ }^{1} \mathrm{H}-\mathrm{NMR}$ spectroscopy $(\mathrm{Q} 2=0.838)$ and UHPLC-QTOF mass spectrometry $\left(\mathrm{ESI}^{+}: \mathrm{Q} 2=0.833\right.$; $\mathrm{ESI}^{-}$: $\left.\mathrm{Q} 2=0.976\right)$ can function as good predictors to determine bee species origins of stingless bee honey. An accurate prediction of bee species origins by such good predictors i.e., discriminant metabolites $\left({ }^{1} \mathrm{H}-\mathrm{NMR}\right.$ spectral data) and diagnostic ions (UHPLC-QTOF mass spectrometric data) for the determination of honey originality has been established.

\section{Discussion and Conclusions}

D-Fructofuranose was described as a discriminant metabolite for H. itama honey, whereas $\beta$-D-Glucose, D-Xylose, and $\alpha$-D-Glucose were responsible for the discrimination of G. thoracica honey (Table 3). The hydrolysis of sucrose from nectar into D-Glucose and D-Fructofuranose is mainly catalysed by invertase enzymes (sucrase, glucosidase, transglucosidase), which are secreted by cephalic glands of stingless bee workers [39,40]. D-Xylose was also found in the honey as reported by Ohmenhaeuser et al. [25]. 
Acetic and L-Lactic acids of T. apicalis honey (Table 3) are the products of fermentation from carbohydrates. Basically, there are three main categories of fermentation in stingless bee honey: Alcoholic, acetic, and lactic fermentation. The alcoholic fermentation (indicated by bubbles and foam) is performed by yeasts, which convert carbohydrates (sugar) into alcohol and $\mathrm{CO}_{2}$. Subsequently, acetic fermentation is performed under aerobic conditions by certain strains of bacteria (commonly Bacillus), which convert alcohol molecules and $\mathrm{O}_{2}$ into acetic acid and water. In addition, lactic fermentation can occur when bacteria mostly convert carbohydrates into lactic acid and water or other organic molecules although yeasts and other fungi can perform similar function. However, those three categories of fermentation can naturally be mixed in stingless bee honey via enzymatic reaction of those microorganisms [40]. Another discriminant metabolite of T. apicalis was L-Alanine (Table 3), which also found in the honey as reported by Boffo et al. [41].

QTOF MS-based identification of metabolites may consist of three main steps, i.e., characterization of metabolites guided by mass spectral database, validation of metabolite structure, and confirmation of metabolite identity (targeted metabolite profiling) [42]. In this study, diagnostic RT, $m / z$ values of precursor ions $\left(\mathrm{ESI}^{+}\right.$and $\mathrm{ESI}^{-}$), and MS-MS fragment ions as well as their corresponding intensities of detected ions represent as distinct ESI-MS fingerprints for each type of stingless bee honey. However, characterization of all diagnostic ions could not be completed $m / z$ values of precursor ions could not be matched with MS-MS fragment ions in any databases.

The present study demonstrates the feasibility of using untargeted metabolomics approach for rapid classification of raw stingless bee honeys by bee species origins. Two complementary approaches, ${ }^{1} \mathrm{H}-\mathrm{NMR}$ and UHPLC-QTOF MS are more appropriate for honey quality control. ${ }^{1} \mathrm{H}-\mathrm{NMR}$ spectroscopy provides rapid detection by minimum sample preparation, non-destruction of the samples, and high reproducibility of data. These advantages are complemented by the UHPLC-QTOF MS, which enables high sensitivity or trace-level detection of metabolites with only minimal amounts of sample. LCMS also provides the possibility to extend the range of compounds detected by using different ion sources (e.g., electrospray ionization or atmospheric chemical ionization) and/or ion modes (positive and negative). The variability of metabolites detected exhibits the complementary nature of ${ }^{1} \mathrm{H}-\mathrm{NMR}$ spectroscopy and UHPLC-QTOF MS techniques (Tables 3 and $4(\mathrm{a}-\mathrm{c})$ ).

Nevertheless, the numbers of bee species origins involved in the present study were limited to only three stingless bee species. Further research need to be conducted on many other species of stingless bee, as mentioned by Schwarz [43] and Rasmussen [44] in more diversified geographical coverage of beekeeping areas.

In conclusion, this study showed that stingless bee honeys can be classified by bee species origin (as reliable classifier) using a robust untargeted metabolomics approach to determine the honey originality. As a result, this study may give a significant impact to the global meliponiculture and apiculture industries in improving the efficiency of honey quality control.

Supplementary Materials: The supplementary materials are available online.

Author Contributions: I.S.I., M.T.A.R., and K.S. conceived this research and designed experiments; Z.Z. and M.Z.M.I. participated in the design; M.M., A.K., and F.A. participated in the interpretation of the data; M.T.A.R. and Z.A.Z. performed experiments and analysis; Y.S.L. and L.L.R. performed partly on the LCMS experiments; M.T.A.R. wrote the paper, and I.S.I. and K.S. participated in the revisions of it. All authors read and approved the final manuscript.

Funding: This research received Fundamental Research Grant Scheme (Project No. 07-02-14-1584FR) from the Ministry of Higher Education (MOHE), Malaysia.

Acknowledgments: The authors wish to acknowledge the Ministry of Higher Education (MOHE), Malaysia for financial support under the Fundamental Research Grant Scheme (Project No. 07-02-14-1584FR).

Conflicts of Interest: The authors declare that they have no potential conflict of interest in relation to the study in this paper. 


\section{References}

1. Codex Alimentarius Commission. Standard for Honey Codex Stan 12-1981, 12Codex Stan 1-8. 2001. Available online: http://www.fao.org/fao-who-codexalimentarius/sh-proxy/en/?lnk=1\&url=https\% 253A\%252F\%252Fworkspace.fao.org\%252Fsites\%252Fcodex \%252FStandards\%252FCODEX\%2BSTAN\% 2B12-1981\%252Fcxs_012e.pdf (accessed on 1 August 2018).

2. Vit, P.; Oddo, L.P.; Marano, M.L.; Mejias, E.S. Venezuelan stingless bee honeys characterized by multivariate analysis of physicochemical properties. Apidologie 1998, 29, 377-389. [CrossRef]

3. Vit, P.; Medina, M.; Enríquez, M.E. Quality standards for medicinal uses of Meliponinae honey in Guatemala, Mexico, and Venezuela. Bee World 2004, 85, 2-5. [CrossRef]

4. Jandrić, Z.; Haughey, S.A.; Frew, R.D.; McComb, K.; Galvin-King, P.; Elliott, C.T.; Cannavan, A. Discrimination of honey of different floral origins by a combination of various chemical parameters. Food Chem. 2015, 189, 52-59. [CrossRef] [PubMed]

5. Leeder, J. Honey Laundering: The Sour Side of Nature's Golden Sweetener. Available online: https://www.theglobeandmail.com/technology/science/honey-laundering-the-sour-side-ofnatures-golden-sweetener/article562759/ (accessed on 5 January 2011).

6. Bogdanov, S.; Vit, P.; Kilchenmann, V. Sugar profiles and conductivity of stingless bee honeys from Venezuela. Apidologie 1996, 27, 445-450. [CrossRef]

7. Mateo, R.; Bosch-Reig, F. Sugar profiles of Spanish unifloral honeys. Food Chem. 1997, 60, 33-41. [CrossRef]

8. Vit, P.; Sancho, T.; Pascual, A.; Deliza, R. Sensory perception of tropical pot honeys by Spanish consumers, using free choice profile. J. ApiProd. ApiMed. Sci. 2011, 3, 174-180. [CrossRef]

9. Aboud, F.; De Pasquale, C.; Sinacori, A.; Massi, S.; Conte, P.; Alonzo, G. Palynological, physico-chemical and aroma characterization of Sicilian honeys. J. ApiProd. ApiMed. Sci. 2011, 3, 164-173. [CrossRef]

10. Almeida-Muradian, L.B.; Matsuda, A.H. Physicochemical parameters of Amazon Melipona Honey. Quim. Nova 2007, 30, 707-708. [CrossRef]

11. Arvanitoyannis, I.S.; Chalhoub, C.; Gotsiou, P.; Lydakis-Simantiris, N.; Kefalas, P. Novel quality control methods in conjunction with chemometrics (multivariate analysis) for detecting honey authenticity. Crit. Rev. Food Sci. Nutr. 2005, 45, 193-203. [CrossRef] [PubMed]

12. Karabagias, I.K.; Badeka, A.V.; Kontakos, S.; Karabournioti, S.; Kontominas, M.G. Botanical discrimination of Greek unifloral honeys with physico-chemical and chemometric analyses. Food Chem. 2014, 165, 181-190. [CrossRef] [PubMed]

13. Pucciarelli, A.B.; Schapovaloff, M.E.; Kummritz, S.; Señuk, I.A.; Brumovsky, L.A.; Dallagnol, A.M. Microbiological and physicochemical analysis of yateí (Tetragonisca angustula) honey for assessing quality standards and commercialization. Rev. Argent. Microbiol. 2014, 46, 325-332. [CrossRef]

14. Serrano, S.; Villarejo, M.; Espejo, R.; Jodral, M. Chemical and physical parameters of Andalusian honey: Classification of Citrus and Eucalyptus honeys by discriminant analysis. Food Chem. 2004, 87, 619-625. [CrossRef]

15. Silva, T.M.S.; Dos Santos, F.P.; Evangelista-Rodrigues, A.; Da Silva, E.M.S.; Da Silva, G.S.; De Novais, J.S.; Camara, C.A. Phenolic compounds, melissopalynological, physicochemical analysis and antioxidant activity of jandaíra (Melipona subnitida) honey. J. Food Compos. Anal. 2013, 29, 10-18. [CrossRef]

16. De Almeida-Muradian, L.B.; Stramm, K.M.; Estevinho, L.M. Efficiency of the FT-IR ATR spectrometry for the prediction of the physicochemical characteristics of Melipona subnitida honey and study of the temperature's effect on those properties. Int. J. Food Sci. Technol. 2014, 49, 188-195. [CrossRef]

17. Guerrini, A.; Bruni, R.; Maietti, S.; Poli, F.; Rossi, D.; Paganetto, G.; Sacchetti, G. Ecuadorian stingless bee (Meliponinae) honey: A chemical and functional profile of an ancient health product. Food Chem. 2009, 114, 1413-1420. [CrossRef]

18. Anklam, E. A review of the analytical methods to determine the geographical and botanical origin of honey. Food Chem. 1998, 63, 549-562. [CrossRef]

19. Hall, R.D. Plant metabolomics: From holistic hope, to hype, to hot topic. New Phytol. 2006, 169, $453-468$. [CrossRef] [PubMed]

20. Kuballa, T.; Brunner, T.S.; Thongpanchang, T.; Walch, S.G.; Lachenmeier, D.W. Application of NMR for authentication of honey, beer and spices. Curr. Opin. Food Sci. 2018, 19, 57-62. [CrossRef] 
21. Beretta, G.; Caneva, E.; Regazzoni, L.; Bakhtyari, N.G.; Maffei Facino, R. A solid-phase extraction procedure coupled to ${ }^{1} \mathrm{H}-\mathrm{NMR}$, with chemometric analysis, to seek reliable markers of the botanical origin of honey. Anal. Chim. Acta 2008, 62, 176-182. [CrossRef] [PubMed]

22. Etzold, E.; Lichtenberg-Kraag, B. Determination of the botanical origin of honey by Fourier-transformed infrared spectroscopy: An approach for routine analysis. Eur. Food Res. Technol. 2008, 227, 579-586. [CrossRef]

23. Jandrić, Z.; Frew, R.D.; Fernandez-Cedi, L.N.; Cannavan, A. An investigative study on discrimination of honey of various floral and geographical origins using UPLC-QToF MS and multivariate data analysis. Food Control 2017, 72, 189-197. [CrossRef]

24. Lolli, M.; Bertelli, D.; Plessi, M.; Sabatini, A.G.; Restani, C. Classification of Italian honeys by 2D HR-NMR. J. Agric. Food Chem. 2008, 56, 1298-1304. [CrossRef] [PubMed]

25. Ohmenhaeuser, M.; Monakhova, Y.B.; Kuballa, T.; Lachenmeier, D.W. Qualitative and quantitative control of honeys using NMR spectroscopy and chemometrics. ISRN Anal. Chem. 2013, 2013, 1-9. [CrossRef]

26. Schievano, E.; Peggion, E.; Mammi, S. ${ }^{1} \mathrm{H}$ nuclear magnetic resonance spectra of chloroform extracts of honey for chemometric determination of its botanical origin. J. Agric Food Chem. 2019, 58, 57-65. [CrossRef] [PubMed]

27. Zhou, J.; Yao, L.; Li, Y.; Chen, L.; Wu, L.; Zhao, J. Floral classification of honey using liquid chromatography-diode array detection-tandem mass spectrometry and chemometric analysis. Food Chem. 2014, 145, 941-949. [CrossRef] [PubMed]

28. Consonni, R.; Cagliani, L.R. Geographical Characterization of Polyfloral and Chemometrics. J. Agric. Food Chem. 2008, 56, 6873-6880. [CrossRef] [PubMed]

29. Donarski, J.A.; Jones, S.A.; Charlton, A.J. Application of cryoprobe ${ }^{1} \mathrm{H}$ nuclear magnetic resonance spectroscopy and multivariate analysis for the verification of Corsican honey. J. Agric. Food Chem. 2008, 56, 5451-5456. [CrossRef] [PubMed]

30. Vit, P.; Fernandez-Maeso, M.C.; Ortiz-Valbuena, A. Potential use of the three frequently occurring sugars in honey to predict stingless bee entomological origin. J. Appl. Entomol. 1998, 122, 5-8. [CrossRef]

31. Ramón-Sierra, J.M.; Ruiz-Ruiz, J.C.; De La Luz Ortiz-Vázquez, E. Electrophoresis characterisation of protein as a method to establish the entomological origin of stingless bee honeys. Food Chem. 2015, 183, 43-48. [CrossRef] [PubMed]

32. Kek, S.P.; Chin, N.L.; Tan, S.W.; Yusof, Y.A.; Chua, L.S. Classification of Honey from Its Bee Origin via Chemical Profiles and Mineral Content. Food Anal. Methods 2016, 10, 19-30. [CrossRef]

33. Vit, P.; Soler, C.; Tomás-Barberán, F.A. Profiles of phenolic compounds of Apis mellifera and Melipona spp. honeys from Venezuela. Zeitschrift Fur Lebensmittel-Untersuchung Und-Forschung 1997, 204, 43-47. [CrossRef]

34. Kim, H.K.; Choi, Y.H.; Verpoorte, R. NMR-based metabolomic analysis of plants. Nat. Protoc. 2010, 5, 536-549. [CrossRef] [PubMed]

35. Katajamaa, M.; Miettinen, J.; Orešič, M. MZmine: Toolbox for processing and visualization of mass spectrometry based molecular profile data. Bioinformatic 2006, 22, 634-636. [CrossRef] [PubMed]

36. Sawaya, A.C.H.F.; da Silva Cunha, I.B.; Marcucci, M.C.; Aidar, D.S.; Silva, E.C.A.; Carvalho, C.A.L.; Eberlin, M.N. Electrospray ionization mass spectrometry fingerprinting of propolis of native Brazilian stingless bees. Apidologie 2007, 38, 93-103. [CrossRef]

37. Eriksson, L.; Johansson, E.; Kettaneh-Wold, N.; Trygg, J.; Wikstrom, C.; Wold, S. Multi- and Megavariate Data Analysis: Part I: Basic Principles and Applications; Umetrics AB: Umea, Sweden, 2006.

38. Jalil, A.H.; Shuib, I. Beescape for Meliponines: Conservation of Indo-Malayan Stingless Bees; Partridge: Singapore, 2014; pp. 13-212.

39. Bogdanov, S.; Lullmann, C.; Mossel, B.L.; D’Arcy, B.R.; Russmann, H.; Vorwohl, G.; Oddo, L.; Sabatini, A.G.; Marcazzan, G.L.; Piro, R.; et al. Honey quality, methods of analysis and international regulatory standards: review of the work of the international honey commission. Mitt. Lebensm. Hyg. 1999, 90, 108-125.

40. Vit, P.; Pedro, S.R.M.; Roubik, D.W. Pot-Honey A legacy of Stingless Bees. Pot-Honey: A Legacy of Stingless Bees; Springer: New York, NY, USA, 2013; pp. 3-654.

41. Boffo, E.F.; Tavares, L.A.; Tobias, A.C.T.; Ferreira, M.M.C.; Ferreira, A.G. Identification of components of Brazilian honey by ${ }^{1} \mathrm{H}-\mathrm{NMR}$ and classification of its botanical origin by chemometric methods. LWT Food Sci. Technol. 2012, 49, 55-63. [CrossRef] 
42. Zhu, Z.-J.; Schultz, A.W.; Wang, J.; Johnson, C.H.; Yannone, S.M.; Patti, G.J.; Siuzdak, G. Liquid chromatography quadrupole time-of-flight mass spectrometry characterization of metabolites guided by the Metlin database. Nat. Protocol. 2013, 8, 451-460. [CrossRef] [PubMed]

43. Schwarz, H.F. The Indo-Malayan Species of Trigona. Bulletin of The American Museum of Natural History, LXXVI(Art. III); The American Museum of Natural History: New York, NY, USA, 1939; pp. 83-141.

44. Rasmussen, C. Catalog of the Indo-Malayan/Australasian Stingless Bees (Hymenoptera: Apidae: Meliponini). In Zootaxa; Magnolia Press: Auckland, New Zealand, 2008; pp. 1-80.

Sample Availability: Samples of the compounds are not available from the authors.

(C) 2018 by the authors. Licensee MDPI, Basel, Switzerland. This article is an open access article distributed under the terms and conditions of the Creative Commons Attribution (CC BY) license (http:/ / creativecommons.org/licenses/by/4.0/). 